\title{
LIVESTOCK PRODUCTION AND ITS ENVIRONMENTAL COSTS
}

\author{
A PECUÁRIA E SEU CUSTO AMBIENTAL
}

PRODUCCIÓN GANADERA Y SU COSTO AMBIENTAL

\begin{abstract}
Heron José de SANTANa Gordilho
https://orcid.org/0000-0001-8485-3729 / http:/ / lattes.cnpq.br/9247033382457379 / herongordilho@outlook.com Doutor em Direito Público pela UFPE. Professor Associado na Universidade Federal da Bahia (UFBA) e da Universidade Católica de Salvador(UCSAL). Fellow da Acadêmia Mundial de Arte e Ciência. Salvador, BA, Brasil.

SAUlo José CASALI BaHIA

https: //orcid.org/0000-0002-3768-3664 / http://lattes.cnpq.br/7398414546353246 / saulocasalibahia@uol.com.br Doutor em Direito Público pela PUC/SP. Professor Associado na Universidade Federal da Bahia (UFBA). Fellow da Acadêmia Mundial de Arte e Ciência. Juiz Federal.
\end{abstract} Salvador, BA, Brasil.

\begin{abstract}
The article starts from the fact that Livestock Production is generating large amounts of Greenhouse Gas Emissions, setting the sector at the heart of Climate Change and Global Warming debate. With CO2 emissions (and equivalents) in the order of 7.1 gigatonnes a year, Livestock Farming represents $14.5 \%$ of the world emissions of Greenhouse Gases from anthropic activities. Reduction of meat consumption, improvement of productivity and reduction of risks are presented as a strategy of avoiding or preventing damages. Brazilian Mechanisms adopted in Brazil are part of the solution. The article aims to demonstrate that all the necessary measures to avoid the environmental disaster claim to an ethical post-humanist and a Global Strategy, overruling the individualism and nationalism.
\end{abstract}

Keywords: Bioethics; Global Governance; Global Warming; Greenhouse Gas Emissions; Meat Consumption.

\section{RESUMO}

O artigo parte do fato de que a produção de gado está gerando grandes quantidades de emissões de gases de efeito estufa, colocando o setor no cerne do debate sobre as mudanças climáticas e o aquecimento global. Com emissões de CO2 (e equivalentes) na ordem de 7.1 gigatonnes por ano, a Pecuária representa 14,5\% das emissões mundiais de Gases de Efeito Estufa de atividades antrópicas. A redução do consumo de carne, a melhoria da produtividade e a redução dos riscos são apresentados como uma estratégia de prevenção de danos. Os mecanismos brasileiros adotados no Brasil fazem parte da solução. A partir de uma pesquisa bibliográfica e documental, o artigo pretende demonstrar que medidas necessárias para evitar o desastre ambiental exigem um compromisso ético pós-humanista e uma Estratégia Global para além dos individualismos e dos nacionalismos.

Palavras-chave: Bioética; Governança Global; Aquecimento global; Emissão de gases de efeito estufa; Consumo de Carne.

\section{RESUMEN}

El artículo parte del hecho de que la producción de ganado está generando grandes cantidades de emisiones de gases de efecto invernadero, colocando al sector en el centro del debate sobre el cambio climático y el calentamiento global. Con las emisiones de $\mathrm{CO} 2$ (y equivalentes) en el orden de 7.1 gigatonnes al año, la Ganadería representa el $14,5 \%$ de las emisiones mundiales de gases de efecto invernadero de actividades antrópicas. La reducción del consumo de carne, la mejora de la productividad y la reducción de los riesgos se presentan como una estrategia de prevención o prevención de daños. Los mecanismos brasileños adoptados en Brasil forman parte de la solución. A partir de una investigación bibliográfica y documental, el artículo pretende demostrar que medidas necesarias para evitar el 
desastre ambiental exigen un compromiso ético post-humanista y una Estrategia Global más allá de los individualismos y de los nacionalismos.

Palabras clave: Bioética; Gobernanza Global; Calentamiento global; Emisión de gases de efecto invernadero; Consumo de carne.

\section{SUMMARY}

INTRODUCTION; 1 LIVESTOCK PRODUCTION AND ITS ENVIRONMENTAL COSTS; 2 MEANS OF AVOIDING AND PREVENTING DAMAGES; 2.1 Reducing consumption; 2.2 Improving productivity and reducing production damages; 2.3 Brazil's mechanisms; 3 MEANS OF ADOPTING MEANS 3.1 Bioethics and incentives: the necessary incorporation of ethics in industrial practice; CONCLUSION; REFERENCES.

\section{INTRODUCTION}

The article aims to demonstrate that all the necessary measures to avoid an environmental disaster claim to an ethical and a global strategy, must overruling the individualism and nationalism.

This justifying the need for implementation by the Government of economic instruments aimed at inducing the behavioral orientation of rural landowners in the sense of adopting alternative uses of livestock, in order to make the preservation activity profitable.

The Livestock Production is generating large amounts of Greenhouse Gas Emissions, setting the sector at the heart of Climate Change and Global Warming debate. With $\mathrm{CO} 2$ emissions (and equivalents) in the order of 7.1 gigatonnes a year, Livestock Farming represents $14.5 \%$ of the world emissions of Greenhouse Gases from anthropic activities.

Reduction of meat consumption, improvement of productivity and reduction of risks are presented as a strategy of avoiding or preventing damages. Brazilian Mechanisms adopted in Brazil are part of the solution.

The present article is organized in three distinct topics. First, it analyses the environmental impacts related to livestock activity, especially to the one developed from an extensive system, highlighting the decrease in the production of ecosystem services due to the suppression of vegetation for implantation purposes of pasture areas - and the effects of this contingency on human well-being - as well as the harmful consequences of the direct emission of greenhouse gases - GEEs.

Then, a brief presentation will be made on the essential role played by the Public Power in the search for the behavioral orientation of the citizen in the sense of carrying out interesting activities, from a socio-environmental perspective, highlighting, in this trail, the importance of 
the management of economic instruments, especially those imbricated to the idea of the sanctions prizes.

Finally, it will analyze the logic that permeates controlled markets failure by marketable credits, in order to associate the instrument of the Environmental Reserve Quota with the possibility of joint operationalization of the commandments of optimization inscribed on the principles of polluter-payer and protector and therefore to the possibility of using it as an instrument capable of stimulating the economic exploitation of rural property in an alternative way to extensive livestock farming.

\section{LIVESTOCK PRODUCTION AND ITS ENVIRONMENTAL COSTS}

It has been mentioned that the world is entering or may have even entered in the Anthropocene Epoch from the Holocene Epoch, because human activity is having a significant global impact on the Earth's ecosystems ${ }^{1}$. For many people, even the Holocene Epoch is already defined by its primary characteristic: the global changes caused by human activity.

Livestock production is at the heart of Climate Change and Global Warming debate ${ }^{2}$.

In an official statement at the 70th United Nations General Assembly on Sustainable Development held in New York on September 27, 2015, the then President of Brazil said emphatically:

[...] Brazil has made great efforts to reduce emissions of greenhouse gases, without compromising our economic development and our social inclusion. [...] Therefore, I want to announce that Brazil's contribution to reducing greenhouse gas emissions will be $37 \%$, by 2025 . By 2030 , our ambition is to achieve a reduction of $43 \%$. I would remind you that in both cases the base year is 2005 . It is in this context that, by 2030, Brazil intends, with regarding to land use and farming: first, the end of illegal deforestation in Brazil; second, the restoration and reforestation of 12 million hectares; third, the restoration of 15 million

\footnotetext{
${ }^{1}$ ZALASIEWICZ $\mathrm{J}$ et al. When did the Anthropocene begin? A mid-twentieth century boundary level is stratigraphically optimal. Quat Int, 2015. 383:204-207.

2 Some ideas in this item were exposed by GORDILHO, Heron; SILVA, Raissa. Cota de reserva ambiental: alternativa sustentável à pecuária extensiva com vistas à redução de emissões de gases de efeito estufa. In: Alana Ramos Araújo; Germana Parente Neiva Belchior; Thaís Emília de Sousa Viegas (Org.). Os impactos das mudanças climáticas no Nordeste brasileiro. 1. ed. Fortaleza/São Paulo: Fundação Sintaf \& Instituto 0 Direito por um Planeta Verde, 2016. Available at: <http://www.planetaverde.org/arquivos/biblioteca/arquivo_20160606234717_1237.pdf> Accessed: April $24,2018$.
} 
hectares of degraded pastures; fourth, the integration of five million hectares of agriculture-cattle raising-forests. ${ }^{3}$

On December 12, 2002, Brazil had already formally reaffirmed its commitment to reducing greenhouse gas emissions in accordance with 195 signatories to the Paris Agreement, which was the product of the 21st Conference of the Parties (COP-21) of the United Nations Framework Convention on Climate Change (UNFCCC). The document symbolizes a remarkable evolution and a communion of efforts at the international plan for the mitigation of climatic adversities. At the novel compromise document, among other elements of extreme importance and actions to be perpetrated by signatories with the purpose of implementing the agreement, there is special emphasis on the following:

55. Recognizes the importance of adequate and predictable financial resources, including for results-based payments, as appropriate, for the implementation of policy approaches and positive incentives for reducing emissions from deforestation and forest degradation, and the role of conservation, sustainable management of forests and enhancement of forest carbon stocks; as well as alternative policy approaches, such as joint mitigation and adaptation approaches for the integral and sustainable management of forests; while reaffirming the importance of non-carbon benefits associated with such approaches; encouraging the coordination of support from, inter alia, public and private, bilateral and multilateral sources, such as the Green Climate Fund, and alternative sources in accordance with relevant decisions by the Conference of the Parties. ${ }^{4}$

Concerns about greenhouse gas emissions (GHGs) do not occur without reason. Over the past 30 years, global warming has risen by 0.6 degrees centigrade and, according to the estimations of James Hansen, former director of the Goddard Institute for Space Studies, NASA's research division, heatwaves and droughts (such as the year of 2011 in Texas, resulting in losses of more than U\$ 5 billion, production losses and spontaneous fires) are only the beginning of

\footnotetext{
3 ÁUDIO do discurso da presidenta da República, Dilma Roussef, durante Sessão Plenária da Conferência das Nações Unidas para a Agenda de Desenvolvimento Pós-2015 - Nova lorque/EUA (8min26s). Portal Planalto, Brasília, September 27, 2015. Available at: <http://www2.planalto.gov.br/centrais-deconteudos/audios/audio-do-discurso-da-presidenta-da-republica-dilma-roussef-durante-sessao-plenariada-conferencia-das-nacoes-unidas-para-a-agenda-de-desenvolvimento-pos-2015-nova-iorque-eua8min26s>. Accessed: April 24, 2018.

${ }^{4}$ UNITED NATIONS. Adoption of the Paris Agreement. United Nations Framework Convention on Climate Change. Paris, 2015. Available at: <http://unfccc.int/resource/docs/2015/cop21/eng/l09r01.pdf >. Accessed: April 24, 2018.
} 
tragedies that may occur due to the increase in carbon and equivalent gases concentration in the atmosphere ${ }^{5}$.

The rise in the emission of greenhouse gases is certainly associated with a demographic explosion. With the rapid population growth, energy and natural resource consumption and industrial production increased significantly, resulting in the emission of tailings and polluting gases. Reason assists to Boaventura de Sousa Santos, when he states that "the demographic explosion becomes a problem when it produces an imbalance between the population and the natural and social resources that they adequately support"6.

In the year 2015, the world population exceeds 7.3 billion. According to data from the Food and Agricultural Organization (FAO), it is estimated that by the year 2050, the mark will reach 9.6 billion$^{7}$.

The demand for food, as a logical sign of the demographic explosion, drives the agricultural sector, and in the last five decades, the world production of meat destined for direct human consumption has quadrupled.

The Brazilian Association of Meat Exporting Industries - ABIEC estimates that, currently, about $20 \%$ of the total area of the Brazilian territory, equivalent to 174 million hectares, is occupied by pastures ${ }^{8}$. Data from the last agricultural census published by the Brazilian Institute of Statistical Geography (IBGE) confirm what the ABIEC estimates, complementing them: in the country, almost three million rural properties are allocated to pastoral activities, so that the Brazilian productive matrix is predominantly extensive (only $3 \%$ of the herd of cattle - estimated at 209 million head in 2011 - is created in intensive confinement systems) ${ }^{9}$.

Despite the growing demand from international markets, $83.5 \%$ of Brazilian production is directed to domestic consumption. So, only $16.5 \%$ of slaughtered animals are directed to

\footnotetext{
${ }^{5}$ HANSEN, James. A mudança climática chegou e é pior do que se pensava. Revista ECO21, Rio de Janeiro, 2012. Available at: <http://www.eco21.com.br/textos/textos.asp?ID=2803>. Accessed: April 24, 2018.

${ }^{6}$ SANTOS, Boaventura de Sousa. Pela mão de Alice: o social e o político na pós-modernidade. São Paulo: Cortez, 2013. p. 288.

${ }^{7}$ GERBER, P.J. et al. Tackling climate change through livestock - A global assessment of emissions and mitigation opportunities. Food and Agriculture Organization of the United Nations (FAO), Rome, 2013. p. 24.

8 PECUÁRIA brasileira. Associação Brasileira de Indústrias Exportadoras de Carnes (Abiec), São Paulo, 2011. Available at: <http://www.abiec.com.br/3_pecuaria.asp>. Accessed: December 15, 2017.

9 INSTITUTO BRASILEIRO DE GEOGRAFIA E ESTATÍSTICA. Censo Agropecuário de 2006: Brasil, grandes regiões e unidades da federação. Rio de Janeiro, 2006. Available at: <http://www.ibge.gov.br/home/estatistica/economia/agropecuaria/censoagro/brasil_2006/Brasil_ censoagro2006.pdf>. Accessed: December 15, 2017. p. 223.
} 
European markets and the United States ${ }^{10}$. The Ministry of Agriculture, Livestock and Food Supply estimates that, by 2050, Brazil will lead a production equivalent to 31.2 million tons of beef per year, projecting a $26.8 \%$ increase in production, when compared to that measured in the year $2010^{11}$.

According to data reported in the FAO Climate Change through Livestock Report, the livestock sector emerges as one of the main responsible for increasing the atmospheric concentration of greenhouse gases, associated negatively to the climate change scenario. With CO2 emissions (and equivalents) in the order of 7.1 gigatonnes a year, livestock farming represents $14.5 \%$ of the world emissions of greenhouse gases from anthropic activities ${ }^{12}$.

In Brazil, greenhouse gas emissions related to agriculture represented, in 2014, a large $60 \%$ of the total indices measured in the country, surpassing the sectors of transportation, fuels and electric energy, according to data extracted from the Report Estimates of Emissions of Greenhouse Gases in Brazil 1970-2014, from the Climate Observatory, published on November 19 of this year ${ }^{13}$.

Regardless of the system adopted, whether intensive or extensive, negative effects on climate and biodiversity are associated with livestock farming, especially in relation to increasing GHG emission levels.

Among the negative results of cattle raising in Brazil, considering the predominant system, that is extensive breeding, it is possible highlight the destruction of natural ecosystems resulting from the suppression of native vegetation in large areas.

The Millennium Ecosystem Assessment (MEA), a research program run by the United Nations (UN) and developed by researchers from more than ninety countries, in the year 2001, with the scope to evaluate the vitality of ecosystems and their relation to human well-being, in a report entitled Ecosystems and Human Well-being: the Framework for Assessment, defines ecosystem as a dynamic complex of interactions between diverse organisms, among animals, plants, microorganisms and elements non-living components of the environment, functioning as

\footnotetext{
10 PECUÁRIA brasileira. Associação Brasileira de Indústrias Exportadoras de Carnes (Abiec), São Paulo, 2011. Available at: <http://www.abiec.com.br/3_pecuaria.asp>. Accessed: December 15, 2017.

11 Ministério da Agricultura, Pecuária e Abastecimento. Agronegócio Brasileiro em Números. Rio de Janeiro, 2010.

12 GERBER, P.J. et al. Tackling climate change through livestock - A global assessment of emissions and mitigation opportunities. Food and Agriculture Organization of the United Nations (FAO), Rome, 2013. p. 1.

${ }^{13}$ Estimativas de Emissões de Gases de Efeito Estufa no Brasil 1970-2014.
} 
an interdependent unit ${ }^{14}$. As organisms interact, produce, acquire or decompose biomass and carbon-based organic components, they not only provide energy material in the form of food but also aid in atmospheric regulation. Ecosystem functions are understood to mean that range of interactions between the elements of an ecosystem that result in energy transfer, nutrient cycling and climate regulation ${ }^{15}$.

To better understand, ecosystem services can be systematized and grouped into four categories: provision services, regulatory services, cultural services, and support services ${ }^{16}$. It is especially interesting here to understand the regulation services, that is, those resulting from the capacity of ecosystems to regulate, from biogeochemical cycles and control mechanisms, the occurrence of processes essential to the subsistence of living beings.

About regulatory services, Sukhdev warns that life on planet Earth is umbilically linked to its provision by natural ecosystems. Reducing the provisioning capacity of regulatory services can lead to serious problems for human well-being. This, therefore, includes the erosion control provided by the vegetation cover and its root systems, the purification and storage of water, and perhaps the most essential to the perpetuation of life, which is the maintenance of the chemical composition of the atmosphere, from the balance between oxygen and carbon dioxide resulting from photosynthetic processes, allowing the accumulation of oxygen fundamental to animal respiration ${ }^{17}$.

In addition to the ecosystemic services of carbon sequestration and storage and maintenance of the atmospheric chemical composition, the vegetal cover plays a second essential role, that is, the climatic regulation. Numerous tree species act as stabilizers of the microclimate, corroborating the balance of the thermal amplitude in the environment in which they are inserted, since they have water in their composition, they take longer to warm up than dry objects, such as rocks and even degraded areas, where uncovered soil radiates heat and reduces the relative humidity of the air. In addition, plant transpiration acts on the heating effect, as each gram of steam from the vegetables takes off approximately 590 kilocalories from

\footnotetext{
${ }^{14}$ ALCAMO, Joseph. Ecosystems and Human Well-being: a Framework for Assessment. Washington: Island Press, 2003. p. 50.

${ }^{15}$ DALY, H.E.; FARLEY, J. Ecological Economics: principles and applications. Washington, DC: Island Press, 2004. p. 74.

${ }^{16}$ ALCAMO, Joseph. Ecosystems and Human Well-being: a Framework for Assessment. Washington: Island Press, 2003. p. 56-60.

17 SUKHDEV, P. The economics of ecosystems and biodiversity. Interim Report of the Convention on Biological Diversity. Cambridge, 2008. p. 15.
} 
the air $^{18}$. In any case, suppression of plant cover in the medium term is imbricated to the phenomenon of desertification.

Primavesi, however, along with the criticisms of extensive cattle-raising, does not exempt the association of intensive livestock farming with the degradation of the environment, the suppression of vegetation cover and the emission of greenhouse gases. According to the agronomist and researcher of the Brazilian Agricultural Research Corporation (EMBRAPA), in intensive systems the debate on deforestation and its effects is transferred to the agricultural sector, since the demand for production of food destined for consumption by confined animals is artificially exaggerated ${ }^{19}$.

In this sense, Tavares records that the crescent deforestation in the Brazilian Amazon region is motivated by the expansion of areas for soybean cultivation, so that by 2004, about 1.2 million hectares were converted to this type of plantation. This soybean production is sold to Europe and the United States where it is destined to the consumption of animals in confinement. In addition, along with the extension of agricultural frontiers as a phenomenon associated with intensive livestock, the accumulation of tailings implies the generation of high amounts of nitrous oxide and methane ${ }^{20}$.

Turning back to the direct emission of greenhouse gases due to the extensive agricultural activity, Primavesi is emphatic: "A beef cattle with approximately $350 \mathrm{~kg}$ of live weight in grazing generates between 40 and $70 \mathrm{~kg}$ of methane per year, which is equivalent to 25 times more in terms of $\mathrm{CO} 2$, that is, between 1.0 and $1.7 \mathrm{t}$ per animal per year $\mathrm{CO}$ equivalent." The author points out that in extensive systems the life expectancy of each animal is, on average, three to four years, due to the intense energy wasted in walks in search of fodder and water, which implies great methane production at high $\operatorname{costs}^{21}$.

As noted in previous lines, livestock farming is estimated to contribute $14.5 \%$ of anthropogenic emissions of greenhouse gases, including carbon dioxide, methane and nitrous oxide. Willers explains: "Regarding gas emissions, methane emissions are the result of the enteric fermentation process of the bovine; Of nitrous oxide occur from manure; And carbon

\footnotetext{
${ }^{18}$ PRIMAVESI, Odo. A pecuária de corte brasileira e o aquecimento global. Embrapa Pecuária Sudeste, São Carlos, 2007. p. 13.

19 PRIMAVESI, Odo. A pecuária de corte brasileira e o aquecimento global. Embrapa Pecuária Sudeste, São Carlos, 2007. p. 19.

${ }^{20}$ BERMANN, Célio; DOMINGUES, Marina Soares. 0 arco de desflorestamento na Amazônia: da pecuária à soja. Revista Ambiente e Sociedade, São Paulo, v. 15, n. 2, 2012.

21 PRIMAVESI, Odo. A pecuária de corte brasileira e o aquecimento global. Embrapa Pecuária Sudeste, São Carlos, 2007. p. 18.
} 
dioxide due to changes in land use, mainly by deforestation, caused by the expansion of pastures and areas of grain cultivation"22.

As punctuated, the survival of living beings is closely linked to the continuity of the provision of services by the ecosystems in which they are inserted. However, the degradation of ecosystems has reached alarming levels, especially since the twentieth century, due to the market and technical advances ${ }^{23}$. The unrestricted development of livestock activity represents a serious risk to the safeguard of the natural processes essential to the survival of species.

\section{MEANS OF AVOIDING AND PREVENTING DAMAGES}

\subsection{Reducing consumption}

If the meat consumption is so dangerous, the first solution appears to be a consumption reduction. There are some reasons for that, but it is not quite that simple.

The International Agency for Research on Cancer of the World Health Organization announced in 2015 that red and processed meat has carcinogenic traits. This relationship was observed with colorectal cancer, the pancreas and the prostate. Red meat (understood as that derived from mammals) has been classified as possibly carcinogenic to humans, while processed meat (the one that undergoes taste-enhancing processes, such as sausage and ham) has been classified as carcinogenic to humans. It demonstrates that the industrial handling of meat increases the risk of harm to human health. For every $50 \mathrm{~g}$ of processed meat eaten daily, the risk of developing colorectal cancer increases by $18 \% .^{24}$

As Mario Herrero et al. already exposed, the resource-use efficiency of livestock is lower than crops, and $1 / 3$ of the world's cereal production is destined to feed animals. They stablished a relationship between the reduction of meat consumption and the reduction of food consumption, since the cattle appears as an intermediary of proteins. "On average," they say, "the production of beef protein requires about 50 times more land than the production of vegetable proteins, and GHG emissions excluding land-use change are about 100 times higher.

\footnotetext{
22 WILLERS, Camila Daniele. Avaliação dos impactos ambientais da pecuária de corte semi- intensiva. Dissertação, Bahia: UESB, $2014 . \quad$ Available <http://www.uesb.br/ppgca/dissertacoes/2014/Camila.pdf>. Accessed: April 24, 2018. p. 22.

${ }^{23}$ AZEVEDO, Plauto Faraco. Ecocivilização. São Paulo: Revista dos Tribunais, 2008. p. 80.

${ }^{24}$ WOLRD HEALTH ORGANIZATION. Monographs evaluate consumption of red meat and processed meat. International Agency for Research on Cancer. Press Release $\mathrm{n}^{\circ}$ 240, October 262015 . Available at: <https://www.iarc.fr/en/media-centre/pr/2015/pdfs/pr240_E.pdf> Accessed: April 24, 2018.
} 
Although meat now represents only $15 \%$ of the total energy in the global human diet, approximately $80 \%$ of agricultural land is used for animal grazing or the production of feed and fodder for animals, but this does include extensive grasslands in areas where other forms of agriculture would be extremely challenging." So, with the global adoption of healthy diets adequate food production in 2050 could be achieved on less agricultural land than is used at present, allowing the regrowth of natural vegetation and resulting in a reduction of GHG emissions of $4.3 \mathrm{GtCO} 2$ e yr-1 relative to the baseline. And for them, low-meat diet would reduce the mitigation costs, particularly in the energy sector, of achieving a $450 \mathrm{ppm} \mathrm{CO2}$ stabilization target in $2050^{25}$.

Obviously, there are some issues regarding the food security and the possibility of adequate low-meat diet access by low-income communities, but certainly anything can be recognized as a mitigation measure.

The FAO 2013 Report considered that several authors have assessed the hypothetical mitigation potential of different dietary change scenarios (for example, Stehfest et al., 2009; McMichael et al., 2007; Smith et al., 2013), but the perspective was not specially analyzed in $\mathrm{it}^{26}$.

A less radical option is the substitution of the protein from beef to pig or poultry meat, cattle associated to lower GHG emissions ${ }^{27}$.

\subsection{Improving productivity and reducing production damages}

Many technical options exist for the mitigation of GHG emissions along livestock supply chains, and the FAO 2013 Report tried to show all of them, divided into the following categories: 1) options related to feed supplements and feed/feeding management (for $\mathrm{CH} 4$ only); 2) options for manure management which include dietary management, but with a focus on "end-of-pipe" options for the storage, handling and application phases of manure management; 3) animal husbandry options which include animal and reproductive management practices and technologies.

\footnotetext{
25 NATURE CLIMATE CHANGE 6. Greenhouse gas mitigation potentials in the livestock sector. 2016. Available at: <http://www.nature.com/doifinder/10.1038/nclimate2925>. Accessed: April 24, 2018.

${ }^{26}$ GERBER, P.J. et al. Tackling climate change through livestock - A global assessment of emissions and mitigation opportunities. Food and Agriculture Organization of the United Nations (FAO), Rome, 2013. p. 1.

${ }^{27}$ GERBER, P.J. et al. Tackling climate change through livestock - A global assessment of emissions and mitigation opportunities. Food and Agriculture Organization of the United Nations (FAO), Rome, 2013. p. 16.
} 
GHG gases at the Livestock sector are nitrous oxide - N2O, methane - $\mathrm{CH} 4$ and carbon dioxide - $\mathrm{CO} 2$, emissions showed as losses of nitrogen $(\mathrm{N})$, energy and organic matter that reduce efficiency and productivity.

It is estimated by FAO that the sector's emissions could be reduced by approximately 30 percent (about 1.8 gigatonnes $\mathrm{CO}$-eq) if producers at a given system, region and agro-ecological zone were to apply the practices of the 10 percent of producers with lowest emission intensity ( $10^{\text {th }}$ percentile), while keeping the overall output constant. If producers were to apply the practices of the 25 percent of producers with lowest emission intensity (25th percentile), the sector's emissions could be reduced by 18 percent (about 1.1 gigatonnes $\mathrm{CO}$-eq) ) $^{28}$.

The measures defined by FAO as available mitigation options for ruminants are: at animal level (optimize feed digestibility and feed balancing, achieve better animal health, and improve performance through breeding); at herd level (reduce the proportion of the animals in the herd dedicated to reproduction and not to production. This can be achieved by improving feeding, health and genetics - all having an effect on fertility, mortality and age at first calving , but also through herd management practices aimed at reducing age at first calving, adjusting slaughtering weights and ages, and adjusting replacement rates in the dairy herd); at production unit level (in grazing systems: improve grazing and grassland management to increase feed quality and carbon sequestration; in mixed systems: improve the quality and utilization of crop residues and fodder, enhance manure management); and at supply chain level (increase the relative beef production supplied by herds producing both meat and milk, adopt energy efficient practices and equipment, encourage waste minimization along supply chains). There are also interventions for monogastric production at animal level (improve feed balancing, animal health and genetics to increase feed conversion ratios and reduce $\mathrm{N}$ and organic matter excreted per unit of product); at production unit level (produce or source low emission intensity feed, reducing land-use change arising from feed production, improving crop fertilization management as well as the efficiency of energy use in feed production and processing, adopt energy efficient practices and equipment, and enhance manure management); and at supply chain level (foster energy efficiency and use of low emission intensity energy, reduce waste generation along supply chains and increase recycling ${ }^{29}$.

${ }^{28}$ GERBER, P.J. et al. Tackling climate change through livestock - A global assessment of emissions and mitigation opportunities. Food and Agriculture Organization of the United Nations (FAO), Rome, 2013. p. 46.

${ }^{29}$ GERBER, P.J. et al. Tackling climate change through livestock - A global assessment of emissions and mitigation opportunities. Food and Agriculture Organization of the United Nations (FAO), Rome, 2013. p. 84. 
Beside these main emission reduction strategies, FAO talked also about extension and agricultural support services, research and development, financial incentives, regulations and market friction instruments. It's necessary to close the efficiency gap, by policies fostering knowledge transfer, enabling conditions for technology transfer and innovation, removing barriers to and creating incentives for efficiency improvement and even adopting practices of carbon sequestration $^{30}$.

\subsection{Brazil's mechanisms}

In its Nationally Appropriate Mitigation Actions (NAMAS), as considered by FAO in its 2013 Report, Brazil has taken a global leading role in the mitigation of GHG emissions from the livestock sector, committing to a range of ambitious mitigation targets over the ten-year period from 2011 to 2020. These include actions to directly reduce live-stock sector GHG emissions and increase removals in grasslands, restoring grazing land (estimated reduction: 83-104 million tonnes Co2-eq by 2020) and integrating crop-livestock farming (estimated reduction: 16-20 million tonnes Co2-eq by 2020).

The actions were described as:

- reducing deforestation in the Amazon (estimated reduction: 554 million tonnes Co2-eq by 2020);

- reducing deforestation in the Cerrado (estimated reduction: 104 million tonnes Co2-eq by 2020);

- no-till crop planting (estimated reduction: 16-20 million tonnes Co2-eq by 2020); and

- biological fixation of $\mathrm{N}$ (estimated reduction: 16-20 million tonnes Co2-eq by 2020).

In support of these pledges, the Brazilian government established the $A B C$ programme, which provides a credit line for special loans to finance various mitigation practices outlined above, as well as from animal waste treatment, which is estimated to generate a further 6.9 million tonnes Co2-eq in emission reductions by 2020. The $A B C$ programme has an estimated a budget of $\mathrm{R} \$ 197$ billion. While large future gains in mitigation in livestock are anticipated from the $A B C$ programme, strong re- cent growth in cattle productivity has already allowed Brazil to increase the size of its cattle herd in the face of declining rates of deforestation in the Legal

${ }^{30}$ GERBER, P.J. et al. Tackling climate change through livestock - A global assessment of emissions and mitigation opportunities. Food and Agriculture Organization of the United Nations (FAO), Rome, 2013. 
Amazon, since 2004. ${ }^{31}$

Basically, Brazil adopted some of the measures proposed by FAO (see item 2.2) to improve productivity and to reduce production damages.

\section{MEANS OF ADOPTING MEANS}

\subsection{Bioethics and incentives: the necessary incorporation of ethics in industrial practice}

In view of such a scenario of expansion of activities related to extensive livestock farming, especially when considering the applicant's adhesion by smallholders, the need for structural changes in the modus where rural property has been used is proving to be imperative.

The tension between private and collective interests must be analyzed jointly, to allow the Public Power to adopt viable strategies from the socio-economic-environmental perspective, without, however, implying in violation to the juridical prerogatives conferred on citizens.

It fits the Mackaay and Rousseau's observation of the action of members of a collectivity vis-à-vis common goods: "The paradox of collective action stems from the fact that rational individuals are not encouraged to cooperate in the pursuit of common interest". The authors show that the rational individual, instead of adopting behaviors aimed at the achievement of the social interest, assuming part of the costs resulting from such conduct, tends to choose to enter into a dispute veiled by the predominance of private interests and benefits ${ }^{32}$.

In view of this, the regulatory State, in the exercise of its activities, has to manage the appropriate instruments with a view to directing the legislature's behavior towards activities that reduce the emission of greenhouse gases. The issue, at least ideally, is linked to the perspective of creating a super-conform behavior, performing a plus in relation to Environmental conservation (in casu, it is intended to induce the containment of the expansion of the extensive livestock, to the detriment of the maintenance of areas with adequate vegetal cover). In other words, the management of economic instruments, especially the use of incentive techniques, as well as the instruments of communication and command and control that the government entity

${ }^{31}$ GERBER, P.J. et al. Tackling climate change through livestock - A global assessment of emissions and mitigation opportunities. Food and Agriculture Organization of the United Nations (FAO), Rome, 2013. p. 95.

32 MACKAAY, Ejan; ROUSSEAU, Stéphane. Análise Econômica do Direito. Trad. Rachel Sztajn. São Paulo: Atlas, 2015. p. 68. 
has, considering the lawfulness that surrounds the free enjoyment of property, is an alternative to the induction of socially relevant behaviors.

Vans Rensselaer Potter was one of the first authors to use the term "Bioethics" to name what he proposed as a science of survival. For him, a new wisdom was urgently needed to guide the use of knowledge in the sense of improving the quality of life for the mankind. Such a science would be constructed from the science of biology, expanding it through the social sciences and humanities, especially philosophy. Bioethics would therefore represent the union of biological knowledge and human values, the two most important ingredients for the emergence of this new wisdom. Biology should overcome the specialization, incorporating elements that allow it to understand human nature, its relation to nature and offer guidelines for survival ${ }^{33}$.

This new discipline - also referred to as a new branch of biology or a new type of interdisciplinary ethics - called Bioethics, would allow for the establishment of a system of priorities and would be aimed at providing models of lifestyles for peoples, as well as proposing new public policies, which could be a bridge to the future. Political decisions that ignore the limit of biological resources to human needs endanger the nature of the species. Bioethics would be able to integrate various principles of biology, developing a realistic understanding of reality, and being able to offer recommendations in the field of public policy ${ }^{34}$.

In these terms, Bioethics carries with it the challenge of moving beyond disciplinary boundaries in search of ideas that are susceptible of objective verification in terms of the future survival of mankind ${ }^{35}$ and the improvement of the quality of life of future generations. There is a need to reach a consensus among disciplines based, as far as possible, on monitoring trends in environmental quality. The only test to which ideas in the human sciences are subjected, namely acceptance by society, could not be taken care of. The latter can express acceptance for reasons that are not well-founded or for individual short-term gratification, ending up perpetuating ideas that should be forgotten ${ }^{36}$.

Plascencia emphasizes that the author believed that human ethics cannot be separated from a realistic understanding of ecology, and pointed out that many policy decisions are made

\footnotetext{
33 POTTER, Van Rensselaer. Bioética: ponte para o futuro. Trad. Diego Carlos Zanella. São Paulo: Loyola, 2016. p. 27-28.

${ }^{34}$ POTTER, Van Rensselaer. Bioética: ponte para o futuro. Trad. Diego Carlos Zanella. São Paulo: Loyola, 2016. p. 28-31.

35 SINGER, Peter. Ética prática. 3. ed. São Paulo: Martins Fontes, 2002. p. 300-301.

36 POTTER, Van Rensselaer. Bioética: ponte para o futuro. Trad. Diego Carlos Zanella. São Paulo: Loyola, 2016. p. 31-32.
} 
by ignoring the available biological knowledge, challenging it and attacking the future of man and the natural resources that underpin $\mathrm{it}^{37}$.

In 1988, Potter published his second book: Global bioethics, building on the Leopold legacy. In this, he stressed that Bioethics must combine biology with diverse humanistic knowledge, to create a science capable of establishing a system of medical and environmental priorities for an acceptable survival. It would be necessary to take into account the ecology and problems of society on a global scale.

Garcia-Rodríguez, Díaz and Rodríguez-León well systematize that Potter's Bioethics was outlined in two moments. Initially, it was conceived as a bridge between the sciences and the humanities. Subsequently, this concept was incorporated into human diversity and political and economic issues that affect ethical thinking, perfecting what he called Global Bioethics. In recent decades, there has been an increase in interest in its perspective, especially in the emergence and need to confront global issues that call into question the relationship between the natural sciences and ethics, such as the impact of scientific and productive activity on the natural environment ${ }^{38}$.

The authors also point out that Potter's proposal recognizes the multiplicity of truths, the social and historical character of knowledge and that link it to life. Global Bioethics represents a major shift in the conception of the object of science. The scientist needs to understand the practical consequences of the knowledge for the human survival. So, Potter incorporates ethics and moral reflection in the scientific universe. The inquiry into the purpose of knowledge is introduced. Morality, therefore, ceases to be an external social element and becomes an inalienable part of the production of scientific knowledge ${ }^{39}$.

The same scientific knowledge that coined the current system of mass production of meat produces research and data that recognize its environmental risks and the need for change. Science should not be understood as a unit, but rather as a plural discursive space crossed by a multiplicity of interests, including those of an economic order. Incorporating ethics into the production of scientific knowledge, as Van Rensselaer Potter proposes, involves

\footnotetext{
${ }^{37}$ PLASCENCIA, Lilia Benavides. Van Rensselaer Potter, pioneiro de la ética global. Reencuentro, Distrito Federal, 2012. 63: 18-19.

${ }^{38}$ RODRÍGUEZ-GARCÍA, José F.; DÍAS, Carlos Jesús Delgado; RODRÍGUEZ-LEÓN, Gustavo A. Bioética global. Una alternativa a la crisis de la humanidad. Salud en Tabasco, Vilahermosa, v. 15, 2-3: 878-881, maiodez. 2009. Available at: <http://www.redalyc.org/pdf/487/48715008005.pdf>. Accessed: April 24, 2018. p. 878-879.

${ }^{39}$ RODRÍGUEZ-GARCÍA, José F.; DÍAS, Carlos Jesús Delgado; RODRÍGUEZ-LEÓN, Gustavo A. Bioética global. Una alternativa a la crisis de la humanidad. Salud en Tabasco, Vilahermosa, v. 15, 2-3: 878-881, maiodez. 2009. Available at: <http://www.redalyc.org/pdf/487/48715008005.pdf>. Accessed: April 24, 2018. p. $879-880$.
} 
challenging the dominant economic power and adopting apparent "anti-economic" measures that, prior to prioritizing the apparent "health" of the economy, prioritize the health of the being Human, the environment and the planet (and the true economic results). It is necessary to resort to legal instruments capable of imposing limits on predatory practices, in casu, the industrial production of meat as it occurs.

Van Rensselaer Potter, despite calling himself a pragmatic mechanist, understands that human intervention in the environment must be more intelligent and responsible, respecting the forces of nature. In his first work, he expressly recalls Albert Schweitzer's work on the critique of the divorce between knowledge and thought, and the development of a science that reflects, with a wisdom capable of balancing it with other knowledge, reaching the very reconfiguration of what is meant by progress ${ }^{40}$.

This is a focal point for analysis: the notion of progress. Today progress is synonymous with economic progress, a series of figures and rates that do not necessarily reflect what is in the interest of humanity. Although there are data available on the continued depredation of the environment, even produced and conveyed by the UN itself, there are no initiatives in the market that provoke a structural change in the way commodities are produced. This applies to the industrial production of meat, but also to the production of various other products, whose consumption is incessantly stimulated. International agreements on the emission of GHGs, deforestation, among other environmental issues have their targets repeatedly violated. This strictly economic and instrumental rationality needs to be changed, and it is understood that bioethics is a propitious field for this turn.

As far as the industrial production of meat is concerned, David Cassuto points out that there are ethical and ecological elements being disregarded. Inspired by Ulrich Beck's work on risk society, the author notes that overproduction is associated with the creation of hazards. In addition, the risks characteristic of the post-industrial society are less visible, such as the release of toxins in the food chain, reduction of the ozone layer, climate change, among others. In this state of affairs, risk management has become as important as the accumulation of wealth. However, on the same science that creates such risks - like the methodology of confinement - lies the responsibility of identifying them and presenting skillful answers to

40 POTTER, Van Rensselaer. Bioética: ponte para o futuro. Trad. Diego Carlos Zanella. São Paulo: Loyola, 2016. p. 70. 
circumvent them, which makes them distrustful of scientific neutrality and benevolence in this role, and there is also the great influence of those who hold the economic power ${ }^{41}$.

The review of animal relations in an ethical and ecological perspective will involve several steps, among which David Cassuto highlights two. The first would be to recognize that efficiency is an economic principle devoid of a reflexive component. By itself, this observation leads to a rethinking of the relationship between men and nonhuman animals in agriculture and livestock. The second step is the recognition that the current industrial agriculture is a cause of ecological destruction, undermines the global economy and spreads global health problems such as obesity, diabetes and heart disease ${ }^{42}$.

Bioethics can configure the adequate space to include ethical considerations in scientific and industrial practice, in favor of environmental balance.

The rationale for the implementation of such indirect regulation goes back to the lessons of Norberto Bobbio about the promotional function of law. Bobbio assumes the premise that in modern society the purely normative conception of law is not adequate and should give way to a theory which adopts a conception of Law as a promoter and interventionist, capable of inducing the legislated to act accordingly with the socially desired behavior ${ }^{43}$.

For this reason, it should adopt techniques of encouragement, such as the granting of primal responses that make it possible to motivate actions that may break with the conformist model of inertia, stimulating the practice of acts concretely capable of positively impacting the scenario.

Following the line of functional analysis, Ana Luisa Sousa Faria points to the crucial role of the Public Power in the management of environmental goods: "adopt administrative measures that induce the citizen/taxpayer to opt for an economic movement based on respect for the environment and, for the realization of ethics and justice" ${ }^{\prime 4}$.

Environmental public policies - understood as a set of strategies and activities through which the State seeks the achievement of objectives directly related to the achievement of the

41 CASSUTO, David N. Dominando o que você come: o discurso da alimentação. Revista Brasileira de Direito Animal, Salvador, v.4, n. 5, 2009. Available at: <https: //portalseer.ufba.br/index.php/RBDA/article/view/10626/7672>. Accessed: April 24, 2018.

42 CASSUTO, David N. Dominando o que você come: o discurso da alimentação. Revista Brasileira de Direito Animal, Salvador, v.4, n. 5, 2009. Available at: <https://portalseer.ufba.br/index.php/RBDA/article/view/10626/7672>. Accessed: April 24, 2018. p. 86.

43 BOBBIO, Norberto. Da estrutura à função: novos estudos de teoria do Direito.Trad. Daniela Beccccia Versiani. Barueri: Manole, 2007. p. 12.

${ }^{44}$ FARIA, Ana Luisa Sousa. O papel do direito tributário na proteção ao meio ambiente amazônico sob uma análise das idéias de Amartya Sen. In: MARTINEZ, Sergio R.; RIBEIRO, Marcia C. P. Desenvolvimento e meio ambiente. Belo Horizonte: Forum, 2011. p. 19. 
ecological balance with a view to promoting the quality of life - should be based on the creation of a sense of community in which the public interest can override the private demands related to capital.

It is imperative to observe of the guidelines set forth in Agenda 21, which from paragraph 33.16 outline that states "should explore new ways of generating public and private financial resources, among them the use of incentives and economic and fiscal mechanisms." Among the economic instruments included in the range of alternatives that may be adopted by the regulatory State, environmental taxes, conditioned allowances and negotiable exploitation permits stand out.

Therefore, from the understanding of opportunity costs, it is necessary to involve the costs related to preservation to consign not only the expenditures effectively realized to the occasion of the preservationist action, but also that amount that the individual could profit if he practiced a licit action, nonetheless socio-environmentally uninteresting.

In line with the line of argument, Guimarães summarizes, stating that "non-polluting economic activities, therefore, should be encouraged through tax and economic instruments to the detriment of polluters, as a way of reorienting the conduct of polluting agents to adopt new and adequate clean technologies" ${ }^{45}$.

That is, the incentives must be well understood and practiced.

\section{CONCLUSION}

Beside national actions, measures and strategies, the GHG issue needs for collective, concerted and global action. Our plant and its atmosphere is a common and life-essential good.

FAO 2013 Report pointed out that:

Due to the size and complexity of the global livestock sector, concerted and global action by all stakeholder groups (including producers, industry associations, academia, the public sector, intergovernmental organizations, and non-governmental organizations) is needed to design and implement costeffective and equitable mitigation strategies and policies ${ }^{46}$.

45 GUIMARÃES, Renan Eschiletti. Machado. Incentivos fiscais no direito ambiental e a efetivação do princípio do protetor-recebedor na política nacional de resíduos sólidos (lei $n^{\circ} 12.305 / 2010$ ). Porto Alegra: Buqui, 2012. p. 17.

${ }^{46}$ GERBER, P.J. et al. Tackling climate change through livestock - A global assessment of emissions and mitigation opportunities. Food and Agriculture Organization of the United Nations (FAO), Rome, 2013. p. 105. 
It is only by involving all sector stakeholders (private and public sector, civil society, research and academia, and international organizations) that solutions can be developed that address the sector's diversity and complexity. Climate change is a global issue and livestock supply chains are increasingly internationally connected. To be effective and fair, mitigation actions also need to be global ${ }^{47}$.

Unfortunately, the Kyoto Protocol to the UNFCCC establishes legally-binding mitigation targets for developed country signatories, but there are limitations to the effectiveness of the Protocol. Large number of countries didn't agree with concrete compromises with binding effects, and some of them never ratified the Protocol.

Political will, but basically human-centered ethics, are necessary to the unpostponable change in the Livestock sector. Global governance must be accepted, or individualism and nationalism, driving the future of the mankind, will create a road to disaster.

\section{REFERENCES}

ALCAMO, Joseph. Ecosystems and Human Well-being: a Framework for Assessment. Washington: Island Press, 2003.

ÁUDIO do discurso da presidenta da República, Dilma Roussef, durante Sessão Plenária da Conferência das Nações Unidas para a Agenda de Desenvolvimento Pós-2015 - Nova lorque/EUA (8min26s). Portal Planalto, Brasília, September 27, 2015. Available at: http://www2.planalto.gov.br/centrais-de-conteudos/audios/audio-do-discurso-da-presidentada-republica-dilma-roussef-durante-sessao-plenaria-da-conferencia-das-nacoes-unidas-para-aagenda-de-desenvolvimento-pos-2015-nova-iorque-eua-8min26s. Accessed: April 24, 2018.

AZEVEDO, Plauto Faraco. Ecocivilização. São Paulo: Revista dos Tribunais, 2008.

BERMANN, Célio; DOMINGUES, Marina Soares. O arco de desflorestamento na Amazônia: da pecuária à soja. Revista Ambiente e Sociedade, São Paulo, v. 15, n. 2, 2012.

BOBBIO, Norberto. Da estrutura à função: novos estudos de teoria do Direito.Trad. Daniela Beccccia Versiani. Barueri: Manole, 2007.

CASSUTO, David N. Dominando o que você come: o discurso da alimentação. Revista Brasileira de Direito Animal, Salvador, v.4, n. 5, 2009. Available at:

https://portalseer.ufba.br/index.php/RBDA/article/view/10626/7672. Accessed: April 24, 2018.

${ }^{47}$ GERBER, P.J. et al. Tackling climate change through livestock - A global assessment of emissions and mitigation opportunities. Food and Agriculture Organization of the United Nations (FAO), Rome, 2013. p. 16. 
DALY, H.E.; FARLEY, J. Ecological Economics: principles and applications. Washington, DC: Island Press, 2004.

FARIA, Ana Luisa Sousa. O papel do direito tributário na proteção ao meio ambiente amazônico sob uma análise das idéias de Amartya Sen. In: MARTINEZ, Sergio R.; RIBEIRO, Marcia C. P. Desenvolvimento e meio ambiente. Belo Horizonte: Forum, 2011.

GERBER, P.J. et al. Tackling climate change through livestock - A global assessment of emissions and mitigation opportunities. Food and Agriculture Organization of the United Nations (FAO), Rome, 2013.

GORDILHO, Heron; SILVA, Raissa. Cota de reserva ambiental: alternativa sustentável à pecuária extensiva com vistas à redução de emissões de gases de efeito estufa. In: Alana Ramos Araújo; Germana Parente Neiva Belchior; Thaís Emília de Sousa Viegas (Org.). Os impactos das mudanças climáticas no Nordeste brasileiro. 1. ed. Fortaleza/São Paulo: Fundação Sintaf \& Instituto O Direito por um Planeta Verde, 2016. Available at: http://www.planetaverde.org/arquivos/biblioteca/arquivo_20160606234717_1237.pdf. Accessed: April 24, 2018.

GUIMARÃES, Renan Eschiletti. Machado. Incentivos fiscais no direito ambiental e a efetivação do princípio do protetor-recebedor na política nacional de resíduos sólidos (lei $\mathrm{n}^{\circ}$ 12.305/2010). Porto Alegra: Buqui, 2012.

HANSEN, James. A mudança climática chegou e é pior do que se pensava. Revista ECO21, Rio de Janeiro, 2012. Available at: http://www.eco21.com.br/textos/textos.asp?ID=2803. Accessed: April 24, 2018.

INSTITUTO BRASILEIRO DE GEOGRAFIA E ESTATÍSTICA. Censo Agropecuário de 2006: Brasil, grandes regiões e unidades da federação. Rio de Janeiro, 2006. Available at:

http://www.ibge.gov.br/home/estatistica/economia/agropecuaria/censoagro/brasil_2006/Brasi I_censoagro2006.pdf. Accessed: December 15, 2017. p. 223.

MACKAAY, Ejan; ROUSSEAU, Stéphane. Análise Econômica do Direito. Trad. Rachel Sztajn. São Paulo: Atlas, 2015.

Ministério da Agricultura, Pecuária e Abastecimento. Agronegócio Brasileiro em Números. Rio de Janeiro, 2010.

NATURE CLIMATE CHANGE 6. Greenhouse gas mitigation potentials in the livestock sector. 2016. Available at: http://www.nature.com/doifinder/10.1038/nclimate2925. Accessed: April 24, 2018.

PECUÁRIA brasileira. Associação Brasileira de Indústrias Exportadoras de Carnes (Abiec), São Paulo, 2011. Available at: http://www.abiec.com.br/3_pecuaria.asp. Accessed: December 15, 2017.

PLASCENCIA, Lilia Benavides. Van Rensselaer Potter, pioneiro de la ética global. Reencuentro, Distrito Federal, 2012. 
POTTER, Van Rensselaer. Bioética: ponte para o futuro. Trad. Diego Carlos Zanella. São Paulo: Loyola, 2016.

PRIMAVESI, Odo. A pecuária de corte brasileira e o aquecimento global. Embrapa Pecuária Sudeste, São Carlos, 2007.

RODRÍGUEZ-GARCÍA, José F.; DÍAS, Carlos Jesús Delgado; RODRÍGUEZ-LEÓN, Gustavo A. Bioética global. Una alternativa a la crisis de la humanidad. Salud en Tabasco, Vilahermosa, v. 15, 2-3: 878-881, maio-dez. 2009. Available at: http://www.redalyc.org/pdf/487/48715008005.pdf. Accessed: April 24, 2018.

SANTOS, Boaventura de Sousa. Pela mão de Alice: o social e o político na pós-modernidade. São Paulo: Cortez, 2013.

SINGER, Peter. Ética prática. 3. ed. São Paulo: Martins Fontes, 2002.

SUKHDEV, P. The economics of ecosystems and biodiversity. Interim Report of the Convention on Biological Diversity. Cambridge, 2008.

UNITED NATIONS. Adoption of the Paris Agreement. United Nations Framework Convention on Climate Change. Paris, 2015. Available at: http://unfccc.int/resource/docs/2015/cop21/eng/l09r01.pdf. Accessed: April 24, 2018.

WILLERS, Camila Daniele. Avaliação dos impactos ambientais da pecuária de corte semiintensiva. Dissertação, Bahia: UESB, 2014. Available at: http://www.uesb.br/ppgca/dissertacoes/2014/Camila.pdf. Accessed: April 24, 2018.

WOLRD HEALTH ORGANIZATION. Monographs evaluate consumption of red meat and processed meat. International Agency for Research on Cancer. Press Release $n^{\circ}$ 240, October 262015. Available at: https://www.iarc.fr/en/media-centre/pr/2015/pdfs/pr240_E.pdf. Accessed: April 24, 2018.

ZALASIEWICZ J et al. When did the Anthropocene begin? A mid-twentieth century boundary level is stratigraphically optimal. Quat Int, 2015. 383:204-207.

\section{COMO FAZER A REFERÊNCIA DO ARTIGO (ABNT):}

GORDILHO, Heron José de Santana; BAHIA, Saulo José Casali. Livestock production and its environmental costs. Revista Eletrônica do Curso de Direito da UFSM, Santa Maria, RS, v. 13, n. 1, p. 319-339, abr. 2018. ISSN 1981-3694. Disponível em: < https://periodicos.ufsm.br/revistadireito/article/view/29434 >. Acesso em: dia mês. ano. doi: http://dx.doi.org/10.5902/1981369429434 . 